\title{
ISSUED BILLS OF LADING BASED ON CHARTER PARTY CONTRACT OF IRAN AND INTERNATIONAL LEGAL SYSTEM
}

\section{CONHECIMENTO DE EMBARQUE EMITIDO COM BASE NO CONTRATO DE FRETAMENTO DO IRÃ E SISTEMA JURÍDICO INTERNACIONAL}

\section{ABSTRACT}

Saeed Hamzeii ${ }^{1}$

Lawyers, who follow the Anglo-Saxon legal system, divide marine transportation contracts into two groups of bill of lading and charter party.

Bill of lading is a document which attests to a marine transportation contract; and the delivery or loading of the goods by the carrier, in accordance to which the carrier pledges to deliver the item to the receiver, whose name has been mentioned in it, or to the holder of the document.

Charter party is a contract, based on which the owner of a ship hands over the utilization of the ship (interests of a ship) to a lessee, for a specified period of time, or for one or several determined voyages between specified ports, for the purpose of transportation of cargo or passengers, in return for a clarified rent. This contract is divided into three types, including; journey-based, temporal-based and non-shared based contracts.

Issuance of the bill of lading shows the presence of a transportation contract between a sender and a carrier. Meanwhile, it should be noted that the said document does not provide a solid and certain proof of fulfillment of all contractual conditions; because the corresponding conditions could have changed in accordance with the charter party contract; documents released by the owner of the ship; and/or the verbal commitment of the parties to the contract. Furthermore, the bill of lading is tantamount to the receipt of items which have been mentioned in it. However, it should not be considered as certain proof of delivery of the items. Thus, English legal texts refer to it as an apparent proof. Also, the bill of lading is synonymous to the goods' title deed, and therefore, its holder can receive the items, as the owner; by rendering the document. The acceptance of such a role for the bill of lading is rooted in the global trade conditions. In other words, given the need for speed in commercial affairs, the holder of the bill of lading is considered as the owner of the items mentioned in it in a bid to expedite the unloading and delivery of the goods to the owner.

Keywords: international law, charter party contract, bills of lading, shipping, global trade, marine transport.

Master of International Law, Central Tehran Branch, Islamic Azad University, Tehran ,Iran. Islamic Azad ${ }^{1}$ University e-mail: saeid.hamzeheii@gmail.com 


\section{RESUMO}

Os advogados, que seguem o sistema jurídico anglo-saxão, dividem os contratos de transporte marítimo em dois grupos de conhecimento de embarque e fretamento.

Conhecimento de embarque é um documento que atesta um contrato de transporte marítimo e a entrega ou carregamento das mercadorias pelo transportador, de acordo com o qual o transportador se compromete a entregar o item ao destinatário, cujo nome tenha sido mencionado nele, ou ao titular do documento.

A parte fretada é um contrato, com base no qual o proprietário de um navio entrega a utilização do navio (interesses de um navio) a um arrendatário, por um período de tempo especificado, ou para uma ou várias viagens determinadas entre portos especificados, pelo objetivo do transporte de carga ou passageiros, em troca de um aluguel esclarecido. Este contrato é dividido em três tipos, incluindo; contratos baseados em jornada, temporal e não compartilhados.

A emissão do conhecimento de embarque mostra a presença de um contrato de transporte entre um remetente e uma transportadora. Entretanto, deve-se notar que o referido documento não fornece uma prova sólida e certa do cumprimento de todas as condições contratuais; porque as condições correspondentes poderiam ter sido alteradas de acordo com o contrato da parte fretada; documentos liberados pelo proprietário do navio; e / ou o compromisso verbal das partes no contrato. Além disso, o conhecimento de embarque é equivalente ao recebimento dos itens mencionados nele. No entanto, não deve ser considerado como prova de entrega dos itens. Assim, os textos legais em inglês se referem a ele como uma prova aparente. Além disso, o conhecimento de embarque é sinônimo da escritura da mercadoria e, portanto, seu detentor pode receber os itens como proprietário; renderizando o documento. A aceitação de tal papel para o conhecimento de embarque está enraizada nas condições comerciais globais. Em outras palavras, dada a necessidade de agilidade nos negócios comerciais, o detentor do conhecimento de embarque é considerado o proprietário dos itens mencionados, em uma tentativa de agilizar a descarga e a entrega das mercadorias ao proprietário.

Palavras-chave: direito internacional, contrato de fretamento, conhecimentos de embarque, remessa, comércio global, transporte marítimo.

\section{INTRODUCTION}

The concept of shipping is not new and the Irans have been familiar with it from time immemorial. The maritime laws referred to as the power of marine transportation and defined as the set of rules guiding the relationship among persons in this field; and also an advanced scientific major which observes the formation, changing, interpretation and analysis of laws related to this field, is a new subject in the legal system and academic society of Iran. In 1964, an Iranian legislator made a 
maritime law, which did not originate from the general legal system of Iran, but was rather a translation of obsolete French business law and international conventions most of which are now revised and changed. However, Iran has sufficed with these obsolete laws to solve the cases of this field.

The ship is an integral element in maritime laws and goods carriage through the sea. The manipulation of ship is allowed by two separate contracts. While one is called the affreightment contract, acknowledged by the waybill, and is known as the affreightment contract under the waybill; the other is called the ship-renting contract which is known with the name of its acknowledger, charter party contract. The owners of small cargos are inclined to use the affreightment contract, while the owners of huge cargos who prefer to control the fate of their cargo during carriage, are inclined to use the charter party contract.

These two contracts have two completely different subjects such that while the affreightment contract is concerned with the carriage of cargo, in the charter party contract, the hirer is given the benefits of shipping by the ship-owner. As a result, these two forms of shipping are essentially different, and laws ruling the charter party contracts are supplementary as opposed to the demanding laws of the affreightment contracts.

The laws guiding the affreightment contracts are unified on world-wide level by the codification and enactment of international conventions such as the Brussels's 1924 convention, known as the Hague convention. The Hague conventions of VISBY and Hamburg, and most countries owning a maritime commercial carriage system, submit to the requirements of these conventions regarding their national benefits. But, opposed to this, laws guiding the charter party contracts follow the common laws of each nation and are in a higher level than international common laws. The only effort done here is the unification of charter party contract documents. This very characteristic has caused complicated issues related to the nature of this contract and the conditions of its formation and results. Since there are no common laws in Iranian ports regarding the characteristics of the country's legal system, there is no major related to the law codification of this field, and the rules are generally borrowed from the Western legal system. The analysis of the laws ruling this contract has always been considered as a must in order to adjust them with the general legal system of the country.

\section{1 - REGULATIONS GUIDING THE MARITIME TRANSPORTATION AND OTHER SHIPPING LAWS OF IRAN INCLUDE THESE ITEMS:}

\section{A. Regulations of the civil law, business and custom affairs related to maritime transportation}

Before the formation of maritime laws, maritime transportation issues were solved by refering to the civil and business laws, until articles 513, 516 \& 517 of the civil law and 2, 377 \& 394 of 
business laws were specified for the business deals and carriage contracts. In addition, article 17 and 26 of custom laws also referred to these subjects.

\section{B. Iran's 1946 maritime law}

This law was codified using the second book of French business law, which was based on the Louis XIV's law. Its main focus was on commercial shipping, and important issues such as maritime reassurance, maritime work, issuing of maritime certificates, organization and eligibility of maritime courts, etc. were not considered.

\section{Maritime Regulations and Instruction Codified by Delegation of Ministers}

A lot of principles and rules regarding the charter party contract and the responsibility of maritime carriage curators are guaranteed by the 1964 maritime law and the most important conventions Iran has joined. However, the said conventions (especially the 1924 Brussels convention) have intended to combine and unify the principles of Roman-German legal system of common laws, albeit they are more influenced by the Roman-German system, and in some cases, obvious conflicts with common law principles exist.

The most important maritime conventions that are applicable in Iran are as follows:

1. International Convention for the Unification of Certain Rules of law Relating to the Bills of Lading and Protocol of Signature (Brussels, August 25th, 1924).

2. International Convention for the Unification of Certain Rules Relating to the Carriage of Passengers by Sea, April 1961.

3. International Convention for the Unification of Certain Rules Relating to

the Limitation of Liability of Owners of Sea-going Vessels, August 25th 1924.

\section{THE IRANIAN MARITIME LAW'S DEFINITION OF TRANSPORTATION CONTRACT}

Iranian maritime law defined transportation contract as: "Affreightment contract is only a contract which is made based on maritime bills of lading. Also, similar documents that are related to maritime transportation, which are acknowledged by charter party contract and form a relationship between the ship-owner and ship-charterer, are considered as affreightment contracts ${ }^{2}$."

This definition adapted from section B of article 1 of the August $16^{\text {th }}, 1924$ convention of Brussels, with the aim of unifying some rules of bills of lading, have some points that are worth noting:

\section{1- The Affreightment or carriage contracts are not made unless based on maritime bills of lading or} similar documents.

The Iranian legislator has limited the existence of maritime carriage contract to the formation of bills of lading or similar documents through this saying: "Affreightment contract is only a contract which is made based on bills of lading or similar documents". Thus, making any kind of contract

\footnotetext{
2 - First section of article 52 of Iranian maritime law
} 
between the charter and carriage-curator an invalid transportation contract, without the issuing of bills of lading or similar documents ${ }^{3}$.

\section{2- Affreightment contract should be formed based on maritime bills of lading ${ }^{4}$.}

Maritime bills of lading are a contract in which the full characteristics of the cargo are explained, and the ship-owner or his/her representative signs it, guaranteeing the cargo being delivered to the destination and received by a receptor. Maritime bills of lading or similar documents are considered as receipts ${ }^{5}$.

\section{3- The contract is formed for the sake of cargo transportation.}

Iranian legislator has indicated and emphasized that the aim of the contract is to get the cargo transported. Apparently, the essential role of cargo transportation in shipping, underdevelopment of passenger transportation, low activity of passenger transportation companies, compared to cargo transportation companies, have caused the legislator to ignore the passenger transportation and consequently limit the maritime transportation to affreightment.

\section{4- Referring to every bill of lading which forms a relationship between transportation-curator and} cargo-owner as an affreightment contract.

like the $2^{\text {nd }}$ section of article52 of Iranian maritime law affirms, whenever a bills of lading is formed based on charter party contract, and have a relationship between carriage-curator and cargoowner, it is credited as a transportation contract.

\section{5- Documents similar to bills of lading based on which affreightment and charter party contracts are} made.

"Similar documents" is a term that is referred to in both maritime law and $2^{\text {nd }}$ section of article 1 of international convention, made to unify some of the Brussels bills of lading laws. The purpose of the Iranian legislator is not clear, and there is no information on the kind of documents that are included.

\section{6- Charter party contract}

Maritime law defines charter party contract as: "Charter party contract is a written document which is formed between the ship-owner or his/her legal representative and a charterer, and specifies the conditions of chartering the ship for a certain period of time, or for several trips between certain

\footnotetext{
3 - See: EsnaAshari, Yadollah, Responsibility of Maritime Carriage-Curator (Master's thesis), with guidance of MortezaNajafiEsfadPh.D, 1376, P 24.

4 - Bills of lading or connaissement

5 - Section 7 of article 52 of Iranian Maritime Law. Also in the French Laws, the bills of lading is defined as below:

- Le connaissement (Bill of lading) est un document de transport signé par le transporteur (ou son agent) ou le capitaine du navire cargo (euson agent). Le connaissementest un papier-valeur.llconfirme la prise en charge de la marchandise pour le transport ousamise à bord et les conditions du transport.
} 
ports $^{61}$. It is clear that this contract allows the owner to rent his/her ship, while ownership is maintained. The transfer of the ship's profits to others is different and requires specific conditions.

\section{MARITIME BILLS OF LADING}

In the second half of the $16^{\text {th }}$ century, some papers called "bills of lading" were used as cargo reception, and gradually took the form they have nowadays.

Bills of lading are a document which guarantees carriage and is considered a receipt. It is formed by the transporter or his/her representative. It includes conditions, rules of transportation contract, testimony of cargo-ownership and its owner can possess the cargo. In fact, the bills of lading is a document indicating the possession of cargo by the carriage-curator. The document is issued by the carriage-curator, it is received by the owner as a receipt and the curator commits to transport the cargo, or provide the requirements of carriage from reception place to the destination.

In section 7 of article 52 of Iranian maritime law, the bills of lading is defined as:" Bills of lading is a document in which the full characteristics of cargo is explained and is signed by the ship-owner or his/her representative, and a commitment of delivery and reception is made by it".

Generally, "bills of lading is a transferrable document that testifies the cargo-ownership, which is issued by the carrier or his/her representative after the cargo is received, and indicates the carriage of a certain cargo by the agreed upon vehicle/vehicles(ship, truck, train, airplane, or a mixture of those) for a certain amount of carriage fare".

Bills of lading is a document of carriage, but not the contract itself. It has 3 characteristics:

1- It is a receipt for cargo.

2. It is the cargo-ownership document.

3- It is a tradable document.

However, some bills of ladings are not transferrable, but transferability is in their nature.

Bills of lading document, from a legal point of view is:

1) A receipt with appropriate legal form, issued by the ship-owner or carriage-curator, indicating that the cargo explained conditions is delivered to the certain destination by the agreedupon ship, or at least the curator or owner has received them.

2) A note on the affreightment contract that repeats the conditions mentioned before the formation of bills of lading, by explaining the details.

3) An ownership document which is tradable and enables the owner of document to transfer the cargo by backing-up and handing it on.

\footnotetext{
6 - Article 135 of Iranian maritime law.
} 


\section{INTERNATIONAL CONVENTIONS CONCERNING MARITIME BILLS OF LADING}

The International Law Society's Maritime Law Committee held a conference in Hague, 1921 in order to codify some rules concerning bills of lading, according to which the rights and duties of shipowners and cargo-owners would be unified world-wide. The agreed-upon rules in a diplomatic conference held on August 25. 1924 in Brussels-after revision- were introduced as "The International Convention for the Unification of Certain Rules of Law relating to Bills of Lading ${ }^{7}$-Hague Rules".

This convention was later revised on February 23, 1968, using the VISBY protocol, and was called Hague-VISBY Rules afterwards.

Hague Rules were successful in achieving two primary aims including:standardizing the most important articles of bills of lading; and the revision of disparities between ship-owner responsibilities and cargo-owner responsibilities, regarding any damage to the cargo while transporting. Instead of several articles that deemed the ship-owner irresponsible for any imaginable damage done to the cargo, the Hague Convention divided the responsibility between the ship-owner and cargo-owner. The Hague-VISBY Convention changed the conditions a little bit to the benefit of cargo-owners. But still, these rules were to the benefit of ship-owners, and this disparity was more evident in developing countries.

After taking the preliminary steps, in 1878, UNCTAD shipping company and UN Commission held a diplomatic conference in Hamburg, in order to form a new convention relating to the United Nations Commission on International Trade Law (UNCITRAL). The new convention, "The United Nations Convention on the Carriage of Goods by $\mathrm{Sea}^{8}$ (Hamburg Rules)" was disclaimed as obligatory on November 1, 1992, while twenty countries had approved of the said convention.

There is a half-century interval between the approval of Brussels Convention Relating to the Unification of some Bills of Lading Rules (August 25, 1924) and approval of Hamburg Rules (March 31, 1978). During these years, the international society had undergone many changes and evolutions and found a completely new face, but maritime laws have ruled over the affairs, sticking with the 1924 convention ${ }^{9}$, thus remaining indifferent to those changes.

Brussels Convention, which is presently over 90 years old, was revised very trivially in 1968 and 1979. Other than that, there have not been any revisions in this convention, and it is still ruling over the affairs with its old structure, while there have been major reforms in other transportation fields such as aerial transportation and international terrestrial transportation ${ }^{10}$.

\footnotetext{
7 - The International Convention for the Unification of certain Rules of Law relating to Bills of Lading-Hague Rules

8 - The United Nations Convention on the Carriage of Goods by Sea (Hamburg Rules)

9 - It is worth noting that this convention was formed based on the US and England common laws.

10 - Warsaw 1929 convention ruling over aerial transportation, revised in 1955 and 1975. Bern 1970 convention ruling over terrestrial transportation through railroad, revised in 1980.
} 
In this half-century, the face of maritime transportation has changed, technically, economically and politically. These changes and evolution demand a reform of laws regulating the transportation affairs regarding the new data. Inventions and technical improvements in all fields, especially in maritime transportation, make the carriage of cargo through the sea very different from the similar act in 1924.

There were several countries getting colonized while the 1924 Convention was approved. The independence of these countries in the 1960's and their entrance to the international fields, made the need for revisions in international society. These countries which had the common characteristic of backwardness were trying to enter the international economical field. For this reason, these countries placed emphasis on maritime transportation role in national economy and its positive influence on equilibrium of foreign tradeduring 1960's and 1970's through the UN Trading and Development Conference, and were claiming their own active participation in exporting and importing.

The said countries deemed Brussels 1924 Convention as an obstacle to their demands, and wished for a very necessary revision to be made to it. This convention was very pleasant to the cargocarrier in field of carriage-responsibility. In other words, the carrier countries were benefiting from this convention, while the cargo-owners who were generally from backward countries became a victim to it. With all the aforementioned, the dissatisfaction of this group from the mentioned convention is understandable ${ }^{11}$.

Eventually, with the efforts of these countries, the 1924 Brussels convention was replaced with the Hamburg rules in 1987, through the UN trading and development convention. This convention got indispensable in October 1992; one year after twenty countries signed and approved of it.

Presently, there are four kinds of laws ruling the bills of lading:

1- Hague Rules

2- Hague-VISBY Rules

3- Hamburg Rules

4- None

Again, after all these, the only thing that remained unachieved was a set of unified laws. In addition, in recent years, some countries have codified new rules which are the combinations of Hague-VISBY and Hamburg rules. This has led to multiplicity of duties and responsibilities. Examples of these combinations are the rules of Republic of China, North European countries (Sweden, Norway, Denmark and Finland), Australia and New Zealand. USA has invented its own rules for the Carriage of

11 - For example, according to the $1^{\text {st }}$ section of $2^{\text {nd }}$ part of article 4 of Brussels 1924 convention, the carrier is irresponsible for any kind of damage done to the goods that is caused by acts, ignorance or negligence of curator, staff or shipping agents. 
Goods by Sea Act (COGSA), which can be mentioned as the most extremist set of rules among the international transportation laws.

\section{5- SHIP CHARTERING}

The main subject of maritime laws is the study of different methods for commercial manipulation of the ship. One of the forms of ship-manipulation is such that is done capitally by the ship-owner and under his/her supervision. Usually, ship-manipulation is done by the shipping companies which aim to offer passenger and goods carriage services to people. It happens a lot that the shipping of these companies does not suffice their needs. This makes the shipping companies use ships outside of their own shipping. Charter party contract is a means to achieve this goal. Also, some cargo-owners see chartering ships as the best option for getting their goods carried from some place to the other.

On the opposing side are the ship-owners who participate in maritime carriage affairs by renting their ships to actives of this field.

\section{DEFINITION OF SHIP-CHARTERING AND ITS EXISTENCE}

Some contractors see the charter party contract as one that makes the renter responsible to entrust his/her whole ship or part of it to the charterer for a certain amount of money. The French law of June 18,1966 has mentioned this definition with a little bit of change in its first article, indicating that this contract commits the renter to concede his/her ship to a charterer for a certain amount of fare. Conditions and influences of this contract are set by the contract correspondents ${ }^{12}$.

In some juridical glossaries, ship-chartering is a written document formed between the shipowner and ship-charterer, and includes the rights and commitments of each correspondent. Details related to the ship, cargo and many other things are dependent on each correspondent's consent ${ }^{13}$.

Iranian maritime law in accordance with the mentioned definition and with emphasis on the contract to be written, in article 135 defines the contract as a written document which is formed

\footnotetext{
12 - Par le contrat d'affrètement, le fréteur s'engage, moyennant rémunération, à mettre un navire à la disposition d'un affréteur. Les conditions et les effets de l'affrètement sont définis par les parties au contrat et, à défaut, par les dispositions du présent titre et celles du décret pris pour son application.

13 - Charter party (Latin: charta partita; a legal paper or instrument, divided, i.e.written in duplicate so that each party retains half), a written, or partly written and partly printed, contract between a shipowner and a merchant, by which a ship is let or hired for the conveyance of goods on a specified voyage, or for a defined period.A vessel might also be chartered to carry passengers on a journey.Also, a written contract between shipowner and charterer whereby a ship is hired; all terms, conditions and exceptions are stated in the contract or incorporated by reference.

A charter party is the contract between the owner of a vessel and the charterer for the use of a vessel.The charterer takes over the vessel for either a certain amount of time (a time charter) or for a certain point-to-point voyage (a voyage charter), giving rise to these two main types of charter agreement. There is a subtype of time charter called the demise or bareboat charter.
} 
between the ship-owner or his/her legal representative and determines the conditions of shipchartering for a certain period of time or one or several trips between certain ports.

As it is clear, from the point of view of the Iranian legislator, charter party contract is one that is written and fulfills the desired conditions of each correspondent. Thus, if a contract is formed orally with the fulfilment of all conditions, it is still not accepted by the Iranian maritime law, even if there are evidences and proofs for this agreement.

Based on the Russian Federation Maritime Trading Rules, charter party contract is a document of vehicle-chartering, by which the vehicle-owner is supposed to concede all or a part of the vehicle to the charterer, for carriage of cargo, goods or passengers.

In Russia, it is common to regulate the charter party contract with some rules and a statute.

In charter party contract; the conditions of both correspondents are explained in full details and they are obliged to determine the characteristics, time, and place of ship's reception. The conditions of contract are fulfilled right after it is signed. Thus, based on the existing contract, the shipowner is responsible for failure or delay in delivery ${ }^{14}$.

Article 198 of Russian Federation's Maritime Trading Laws has sufficed with only the temporal definition of charter party contract ${ }^{15}$.

\section{KINDS OF CHARTER PARTY CONTRACT}

Article 136 of the Iranian Maritime Law determines that the whole ship or a part of it be conceded to a charterer for a certain period of time and for one or several trips. The legislator has indirectly mentioned the kinds of charter party contract and thus has allowed the ship-owners and ship-manipulators to form the contracts with a variety of contents. But it should be noted that this division is faulty. It is inferred from the legislator's saying that there are two kinds of charter party contracts: temporal chartering and trip chartering contracts. Article 136 is restricted to these two kinds of charter party contracts, while in other countries ${ }^{16}$; based on the ship's equipment, there are two

\footnotetext{
14 - Чартер в самом широком смысле слова означает договор фрахтования транспортного средства, в соответствии с которым одна сторона (фрахтовщик) обязуется предоставить другой стороне (фрахтователю) за плату всю или часть вместимости одного или нескольких транспортных средств на один или несколько рейсов для перевозки груза, пассажиров и багажа.Порядок заключения, а также форму договора фрахтования устанавливают транспортные уставы и кодексы.В чартере обычно подробно излагают согласованные сторонами условия перевозки груза, а также обязанности сторон, предшествующие перевозке: характеристики, время и место подачи судна и т.д.Условия чартера становятся обязательными с момента его подписания, поэтому фрахтовщик-судовладелец несет предусмотренную договором ответственность за неподачу или опоздание судна.

15 - Определение договора фрахтования судна на время (тайм-чартера)

По договору фрахтования судна на время (тайм-чартеру) судовладелец обязуется за обусловленную плату (фрахт) предоставить фрахтователю судно и услуги членов экипажа судна в пользование на определенный срок для перевозок грузов, пассажиров или для иных целей торгового мореплавания.

16 - For example, maritime laws of France, Switzerland and USA can be referred to.
} 
other kinds of contract as well. Based on this, charter party contract is divided into two categories of chartering equipped ships and chartering unequipped ships.

\section{THE DIFFERENCE BETWEEN BILLS OF LADING AND SHIP-CHARTERING}

The difference between bills of lading and ship-chartering is examined from two aspects:

\section{a) From the aspect of the kind of the contract}

The lawyers following the Anglo-Saxon legal system divide maritime transportation contracts to two categories of bills of lading and ship chartering.

Regarding the descriptions given in various legal texts about the mentioned contracts, the differences between them can be enumerated:

1. Maritime bills of lading is a contract formed between cargo-owner and carriage-curator and commits the carriage-curator to carry the cargo between ports for a certain amount of fare. The shipchartering contract is formed between ship-owner and ship-charterer and the ship-owner is supposed to concede the whole ship or part of it to the charterer for a certain period of time or trip between certain ports.

2. The charter party contract is usually formed for the carriage of huge goods that take the whole or a big part of the ship, because, for example, chartering a whole ship for the carriage of goods like oil is much more economical than other methods of carriage. Then again, bills of lading are used for carriage contracts that concern goods taking a small part of the ship; in addition to the carriage of goods in regular liner shipping, while it is not like that in charter party contract. It is worth noting that the correspondents of charter party contract are usually businessmen, while this is not true of bills of lading.

3. The most important difference between affreightment contract (with bills of lading as its document) and charter party contract, is the rules and legal system regulating them. Bills of lading has Brussels 1924 international convention regulating it with unified rules for the sake of protecting cargoowners' rights and preventing carriage-curators from forcing their own conditions, and a lot of governments have approved of them and let them enter their legal systems as dispensable. However, there are no international conventions formed concerning the charter party contracts. Also, there are no dispensable rules concerning this matter in countries' internal legal systems, and these rules are counted as supplementary or interpretative. In other words, the principle of both respondents' freedom is ruling.

The reason for the rules regulating the charter party contract not being dispensable is that unlike affreightment contract (bills of lading), the contract correspondents have equal economical 
situations, and have similar conditions. The charterers are usually owners of big industries or are shipowners themselves, thus the ship-owners cannot force their conditions on them.

4. Charter party is a personal contract,such that its conditions are effective only on the two contract correspondents; while the conditions of affreightment contract may affect third parties as well. For this reason, should the responsibility of ship-owner decrease, only the cargo-owner suffers disadvantages in charter party contract. On the other hand, if the responsibility of carriage-curator decreases in bills of ladings, third parties may get affected.

\section{b) From the authenticity and value demonstration aspect}

As it was initially mentioned, the bills of lading is one of the most important common documents in maritime carriage and can be counted as a proof for many things such as affreightment contract. Generally, bills of lading can appear in different roles as a document:

1. as a proof of affreightment contract formation

2. as a receipt for goods

3. as a proof of goods-owning

4- as a tradable document

The charter party contract is only seen as a proof of ship-chartering. It is worth noting that unlike charter party contract, bills of lading can only be an alternative for the existence of contract, not a solid proof for its formation, meaning that the opposite is provable. For this reason, some English lawyers claim that: "Bills of lading is analytically just a statement of carriage-curator's opinions about affreghtmen contraction's conditions". Thus, though not mentioned in the bills of lading, the conversations and preliminary agreements of correspondents can affect the affreightment contract. In other words, outer affairs can affect the conditions of affreightment contract. Even so, it is not true of charter party contract, and outer affairs being able to affect the conditions written in the contract.

\section{BILLS OF LADING AS A PROOF OF SHIP-CHARTERING}

When the goods-owner happens to be the ship-owner, the rights of charterer and ship-owner is solely determined with the charter party contract. In this situation, bills of lading cannot be different from charter party contract nor have additional conditions, unless the charter party contract gives the permission explicitly.

But if the charterer is carrying other people's goods with the ship, affreightment contract should be the same with the issued bills of lading without considering the charter party contract of each correspondent, unless in cases that are explicitly agreed upon in opposition to this condition. In addition, in the above case, if the goods-owner is informed about the charter party contract, then, his/her relationship with the charterer is between themselves, meaning that the goods-owner can prosecute or be prosecuted by the charterer if the goods-owner is not informed about the existence 
of charter party contract (because in any way, bills of lading is signed by the ship-commander as a representative of the ship-owner), his/her correspondent would be the ship-owner.

Whenever the cargo-owner who sends his/her cargo with the chartered ship backs up the bills of lading in the name of charterer, the relationship between the ship-owner and the charterer would still be determined with the charter party contract. In any way, the commander is only allowed to sign the charter party contract in accordance with the bills of lading.

When the charterer intends to transfer the rights and duties written in the bills of lading by backing it up, the transferee does not benefit from the conditions of the charter pary contract unless those conditions are mentioned explicitly in one of the articles of bills of lading, or the bills of lading is of a kind that the commander had not been able to issue legally in accordance with charter party contract.

In cases that there are articles in bills of lading that can be interpreted as having conditions of charter party contract, it is worth saying that it should not be figured that the conditions directly relate to lading, carriage or delivery of goods, and they do not create commitments for the charterer, or the commitments are transferred to the bills of lading. In case of responsible-ending conditions, the title of the charterer is changed to the goods-receiver or goods-owner, and if the condition does not exist, it includes the recently mentioned cases, and this inference is not correct.

Exceptional conditions are sometimes added, and the question posed about contract rights is: how much commitment does the acceptance of an additional condition give to the acceptor? This question is posed more in relation to the tickets with limited responsibility for the carriage-curator. The answer to that is: the acceptor of the conditions is committed to the conditions, whether he/she reads it or not, but only if he/she is warned beforehand.

If the ship-owner wishes to include new conditions in bills of lading that exempt him from common loss, he should not only say it orally but should have it written in the document explicitly and in bold alphabets such that an ordinary person can see it.

\section{Trabalho enviado em 22 de dezembro de 2018}

Recebido em 30 de setembro de 2019 